\title{
FAMILY ORGANIZATION FOR THE CARE OF CHILDREN WITH CHRONIC CONDITIONS, DISCHARGED FROM THE NEONATAL INTENSIVE CARE UNIT ${ }^{1}$
}

\author{
Corina Lemos Jamal Nishimoto², Elysângela Dittz Duarte ${ }^{3}$
}

\footnotetext{
${ }^{1}$ Article drawn from the dissertation - Family organization for the care of children with a chronic condition, discharged from the neonatal intensive care unit, the Post-Graduate Program in Nursing at the Federal University of Minas Gerais (UFMG), 2012.

${ }^{2}$ MSC in Nursing. Researcher at the Center for Studies and Research on Nursing Teaching and Practice (NUPEPE). Minas Gerais, Brazil. E-mail: corinajamal@gmail.com

${ }^{3}$ Ph.D. in Child and Adolescent Health. Assistant Professor at the Department of Child Maternal Nursing and Public Health EE-UFMG. Minas Gerais, Brazil. E-mail: elysangeladittz@gmail.com
}

\begin{abstract}
A qualitative study that aimed to examine family organization for the care of children with chronic conditions, discharged from the Neonatal Intensive Care Unit (NICU). The subjects were 12 relatives of children with chronic health conditions. Data were collected through genograms, ecomaps and semi-structured interviews, developed based on the Family Management Style Framework theoretical model and analyzed using thematic content analysis. The organization of families is related to the ongoing care requirements of the children, considering the routines of care established in the period immediately after discharge from the hospital and continuing up to the present. It was established that families access their social networks to handle the required care.
\end{abstract}

KEYWORDS: Chronic disease. Family. Infant, newborn. Intensive care units. Neonatal.

\section{A ORGANIZAÇÃO FAMILIAR PARA O CUIDADO À CRIANÇA EM CONDIÇÃO CRÔNICA, EGRESSA DA UNIDADE DE TERAPIA INTENSIVA NEONATAL}

RESUMO: Estudo de abordagem qualitativa, que teve como objetivo analisar a organização familiar para o cuidado à criança em condição crônica egressa da Unidade de Terapia Intensiva Neonatal. Os sujeitos foram familiares de 12 crianças que apresentam condição crônica de saúde. Os dados foram coletados por meio do genograma, ecomapa e de entrevista com roteiro semiestruturado, elaborado com base no modelo teórico Family Management Style Framework e analisados pela técnica de análise de conteúdo temática. A organização das famílias está relacionada às demandas apresentadas pelas crianças em cada momento vivenciado, considerando o percurso do cuidado estabelecido no período imediatamente após a alta hospitalar até os dias de hoje. Identificou-se que para atender aos cuidados demandados, as famílias acessam as suas redes sociais.

PALAVRAS CHAVE: Doença crônica. Família. Recém-nascido. Unidades de Terapia Intensiva Neonatal.

\section{ORGANIZACIÓN FAMILIAR PARA EL CUIDADO DE NIÑOS EN CONDICIÓN CRÓNICA EGRESADOS DE LA UNIDAD DE CUIDADOS INTENSIVOS NEONATALES}

RESUMEN: Estudio de enfoque cualitativo realizado con el objetivo de analizar la organización familiar para el cuidado de niños con enfermedad crónica después del alta hospitalaria de la Unidad de Cuidados Intensivos Neonatales (UCIN). Los sujetos del estudio fueron familiares de los niños. Los datos se recolectaron a través del genograma, ecomapa y en entrevista con guión semiestructurado elaborado con base en el modelo teórico Family Management Style Framework; luego se analizaron según la técnica del Análisis de Contenido Temático. La organización de las familias está relacionada con la demanda de los niños en cada etapa, considerando la atención establecida para el período posterior al alta hospitalaria y hasta el presente. Se observó que para atender la solicitud de tales cuidados, las familias acceden a sus redes sociales.

PALABRAS CLAVE: Enfermedad crónica. Familia. Recién nacido. Unidades de Cuidado Intensiva Neonatal. 


\section{INTRODUCTION}

Chronic conditions in childhood are defined as those having a biological, psychological or cognitive basis, which have lasted or have the potential to last for at least one year. They also produce sequelae such as limitations in function, activity or social role; dependence on medication, special food, or technological support devices; and the need for health care or related services, and educational services, at levels higher than usual for children of the same age.

It has been found that the increase in chronic conditions in childhood is related to the increased survival rate of infants at high risk who are discharged from the neonatal intensive care unit (NICU), a place with a high concentration of technology and professional expertise. ${ }^{2}$ It has also been found that these infants, especially those born at the threshold of viability, are at increased risk of neurodevelopmental deficits and functional disabilities, as well as asthma, cerebral palsy and visual impairment, ${ }^{3-4}$ setting up a changing childhood epidemiology profile in Brazil.

Studies on the care of children with chronic conditions have sought to analyze their survival ${ }^{3-4}$ and identify the demands for care. ${ }^{3,5-6}$ They are also focused on the organization of health care services for this group ${ }^{7}$ and the repercussions of care for the families. ${ }^{8-9}$

However, as there is not a systematic model of care for these children, often what is observed is that professionals do not yet know how these families organize home care, due to the physical distance between these professionals and the child and the family.

Given the persistence of chronic problems over time, chronic conditions require sustained, long-term care, which the family manages and performs in conjunction with networks of care that it fashions.$^{10}$ However, despite knowledge of these findings, it has been found that the strategies used to ensure such care are still inadequate.

The care is most often provided, not by individuals, but collectively, by people with emotional or blood ties, or in physical proximity. Thus, the following definition of family was adopted: "[...] the family is who the members say they are". ${ }^{11: 48}$ Therefore, the family is considered to be not only people who are united by blood ties or civil union, but also those who are linked by feelings of affection, or those who simply feel they belong to the same group.
By recognizing the potential and accountability of the family in the care of a child with a chronic condition, some authors defend the idea that, in this process, the required professional care practices should focus on the needs of the child and the family. ${ }^{10}$

The care of children with chronic conditions can interfere with everyday family life, demanding new organization for care. The way this process is experienced can favor child care or not, since family support is understood to be that which provides the fullness and continuity of care.

For this research, the care of children with chronic health conditions in the home environment was taken as the object of study, with a focus on the organization of the family. The aim of the study was to analyze the family organization for the care of children with chronic conditions, discharged from the neonatal intensive care unit.

\section{METHODS}

This is a descriptive-exploratory study, with a qualitative approach, underpinned by a dialectic theoretical and methodological framework. This framework guided the approach to the phenomenon under study, comprising families in a particular time and place, with their dynamics and everyday relationships, enabling interactions and transformations, and producing new realities. Furthermore, it is considered that the chronic condition, within the family context, transforms the way of life of the family; at the same time, how these individuals are organized to care for the child can also modify the process or course of the illness.

The study subjects were 12 families of children discharged from the NICU who have a chronic health condition, according to previously determined criteria. ${ }^{1}$ Data collection was conducted at the children's homes. A genogram, an ecomap and an interview with a semi-structured script were adopted as instruments, prepared based on the Family Management Style Framework (FMSF) theoretical model. ${ }^{12}$ The interviews were conducted simultaneously with the people responsible for the child who are considered family members, whether having blood ties or not.

Data collection was conducted from April to July 2012. The interviews were recorded, then transcribed and analyzed for thematic content ${ }^{13}$ with the aim of identifying common themes in all of the empirical data, which, taken together, allowed the explanation of the phenomenon of family 
organization for the care of children with chronic conditions. The genograms and ecomaps, built for each family, were used in a complementary way, contributing to the understanding of family dynamics and the relationships established among family members and the social network. The data provided by the informants was incorporated into the relevant themes during analysis.

In presenting the results, some excerpts from the transcriptions of the interviews were exemplified. The following were adopted for encoding of passages: recording of the member's (informant) role in the family; the numerical identification assigned to each child; and the order of appearance in the interview excerpt (e.g., Mother: 1-5).

For better understanding of the genograms and ecomaps, the children were identified with fictitious names. Abbreviations of fictitious names were also used for family members.

Health services mentioned by the family were coded with letters in alphabetical order according to the sequence in which they appeared in the interviews and categorized as public hospitals, private hospitals, specialized care services, rehabilitation services, the Association for the Parents and Friends of Intellectually Disabled People (APAE, acronym in Portuguese) and health centers.

All stages of the research were conducted in accordance with the regulatory guidelines for research involving human beings; the project was approved by the Research Ethics Committee at the Federal University of Minas Gerais (UFMG), CAAE No. 0616.0.203.000-11. The participants were informed about the goals and purposes of the study and signed a Free and Informed Consent Form.

\section{RESULTS}

The results led to an understanding that family members highlighted aspects related to the organization of the family for the care of children with chronic conditions, experienced by them at different times, considering the course of care established in the period immediately after hospital discharge and continuing up to the present. The chosen strategies were a way to meet the needs of the children at the time and find new ways of getting on with their own lives.

The period following hospital discharge was considered a difficult time for the family, and the children's needs involved breastfeeding, administration of drugs and constant medical supervision:
[...] maintaining this milk [breast], continuing feeding, my breasts were even hurting, wherever I squeezed became bruised. It was not easy at all. (Mother: 2-13;14).

[...] then I would have just lay down to sleep and it was only an hour before he had to take some medication. Then there was the concern with the medication. (Mother: 10-40.1).

That moment was permeated by feelings of fear and insecurity, by the fear of any complications at home and of the child not receiving the necessary care: [...] I went two days without sleeping after she came home, afraid of not knowing how to take care of her. Then I went crazy... two days of being afraid that she would die of suffocation or something. (Mother: 1-14).

It was evident that the initial changes required for the families to adjust meant making considerable changes in their routine and an intense involvement in care, especially by the mother. In some cases, mothers reported the presence of people they could rely on to assist them in whatever way necessary, such as a neighbor: [...] my mother does not live nearby, so I do not have a mother, brother or sister, father. I have a neighbor who comes by, so, by giving that support, sometimes that helps. But the work, likewise, if I could not handle it, washing some clothes... I arranged for someone and paid them. (Mother: 10-44).

The data relating to the ecomap of the Mother's family: 10 reaffirmed that the neighbors are considered sources of support and maintain a strong relationship with the family due to this support.

The occurrence of injuries often led to the need for the rehospitalization of some children. This imposed a further change in the family routine, which had already begun to settle after the hospital discharge. Then, after about seven days... it started leaking [the valve]. Then we were hospitalized, for another long period, nearly two more months. (Mother: 6-7).

In some cases, it was possible to verify fewer demands for visits by health professionals over time, as well as for emergency services. Because now, thank God, so much has improved... because in the beginning, it was like this... he got the flu a lot and I had to rush him to the hospital... every time it was pneumonia [...]. (Mother: 8-27).

Some mothers seemed to protect their children in an attempt to reduce the risks. I just keep looking, oh my God, the head! But the head is not looked after like that so much, the doctor has already explained 
that to me, but that really is something for us to protect, you know? (Mother: 6-35).

We care too much. And sometimes we care so much it hinders. It hinders a little. [...] I did not used to put toys in his hand like that. I did not get him to walk... I did not give him anything to play with. (Mother: 2-6).

As regards the care required by children today, family members pointed to those related to health services; the use of medications and supply of food, which are associated with environmental adaptations; and the need for stimulation through play. Food for him has to be well mashed up. [...] So we have to take great care with his food. He chokes so much. (Grandmother: 12-5).

[...] Sometimes it takes me a little more time to do something, because I want so much to stimulate, care for, give more freedom to him. (Mother: 10-64).

Health services occur in hospitals for outpatient treatment with health professionals and rehabilitation services. Regarding the use of drugs, Mother: 8 states that it is not necessary, due to respiratory problems.

[...] I go straight out. Yesterday the private hydrotherapy started, we are paying to see if it improves his locomotory issue. (Mother: 8-14).

In addition to these measures, the need to always be aware of the child was also reported by family members. But we always try to manage... All of us here take care of him. There is always someone watching, someone taking care... since he was very young, until today... (Mother: 6-65).

Some aspects concerning the care facilities for the child were mentioned by informants. The results showed that the growth and development of the children, behavior changes, and the temporary stability of the condition influenced the way care is perceived. Now, when he goes to the doctor, I am already able to go along with him alone... He comes along in the wheelchair behind, but now he talks to me a little. So it is easier. (Mother: 6-70).

[...] He also has phono treatment, which was to be able to feed. Because before, he did not open his mouth to eat, no way. [...] He now opens his mouth in order to eat... Before, taking a bath was very hard, because when I put him in the bathtub, his whole body went stiff, and he would want to get out of the tub. Now I bathe him sitting in the tub, I bathe him standing up. [...] He no longer chokes like he used to. I used to give him water, he choked on everything I gave him. Today, you can give him water, no bother, he no longer chokes. He already eats without choking. He has improved greatly. [...] He is much easier to deal with. (Mother: 8-32).
Among the informants, some considered that, with the arrival of a child with a chronic condition, there were no changes in routine, while others explicitly expressed these changes.

In the testimony of families who recognized no change in routine, we realized that they associated this situation with certain factors: prior experience in caring for children; considering the fact that the child demands care just like any other child; the existence of a united family, contributing to the achievement of care and dealing with the condition; and the presence of the children's grandparents to assist in care. Furthermore, it was highlighted that the parents do not work outside the home. [...] For me it's the same thing. I have already had to look after fifteen boys. Now, today, I have only four. (Grandmother: 7-38).

It does not hinder much, no. Because like I say, whatever I cannot do at home, my mother does. (Mother: 12-25).

But we do not have this change [in the routine of the family], because both of us do not work outside the home. (Mother: 10-80).

The care provided for children 7 and 12 is performed by their mothers and other family members, especially grandparents. Genograms of these families, as well as of other study participants, show that their formation is not represented by the presence of the parents and child together. These mothers do not have a marital relationship with the children's fathers and therefore reside with family members, who take care of the children with them.

Some family members were emphatic in stating the changes in the family routine. The impossibility of working outside the home as the child becomes a priority emerged in the remarks of some respondents. Among the interviewees, it was noticed that the women took care of the children, whether they were mothers, aunts or grandmothers, which led to changes in their lives. I left for work in the morning, from there I went to class and stayed until nighttime. [...] I led life as I think many people lead it. Work, study, and go home, in a routine. (Mother: 2-31). [...] I even had to leave work to go with him, because his mother does not have much patience. (Father: 11-12).

As it was necessary for some family members to quit their jobs, often household chores were also set aside and changes were established in schedules to be able to attend to the children. But I think mine and B's [mother-in-law] really quit. There are also some days when she does not even tidy the house. 
She spends the whole day here with him. (Mother: 2-34; 35). It is because it is now all over. The business of going out, everything must have a schedule. (Mother: 8-38).

Some families, despite the changes brought about in everyday life, now see the possibility of returning to daily tasks, as they have adapted to care. [...] I even do a lot of things with her, I am used to it already. I have learned. I have learned to do things with her. (Mother: 1-37). Yes, it now looks like it is becoming normal... [daily family life]. (Grandmother: 6-79).

It has also been learned that one way of organizing for care is controlling finances. The family gives up certain activities, such as going for a ride or shopping, because they are thinking about the possibility of needing the money for the purchase of medicine or a medical appointment, for example. If you can do it, then do it, if not... it is not missed. We want to go for a ride, we know we cannot afford it, we cannot go spending on expenses beyond the budget. Because, maybe, we might suddenly need to buy medicine, or have an out-of-hours appointment. (Mother: 10-60).

The testimony of the respondents pointed to how the family is organized with regard to household tasks, in order to accompany the child to health services, and how they manage to juggle work with the actual care that the child demands at home, such as bathing and feeding.

As for household tasks and monitoring health services, it can be noticed that these activities are shared between the parents and some family members and friends. This fact also occurs in situations where one parent works outside the home. Sometimes, when I need to do something that I cannot handle, or when he is tired of staying in the crib, then I ask my aunt who has gone out. I take him there to her house, I leave him there with her for a little while and then I come running. (Mother: 8-34).

[...] who will take him [health service], both of them [the grandmother and the aunt], when one cannot the other can. (Mother: 7-32).

So, we always work well like this, on Saturdays, it's my mother who practically stays there looking after him. So, if need be, it is her and my father that take him to the doctor. And, besides these people, there are many others who follow the whole process and if need be. (Mother: 6-93).

By means of the ecomap of the Mother's family: 6 (Figure 1) it was possible to verify these sources of support mentioned by the family members.

With regard to care like bathing and feeding, the family members divide the tasks among themselves. Generally, during the day, it is me and my mother. At night we leave her in her Grandpa's charge. (Mother: 5-24).

[...] if she [the child's mother] is doing something, I look after him, if I'm doing something, she looks after him. (Grandmother: 12-21).

The support of the grandparents, the aunt and the cousin, who usually reside in the same household as the mother and child, stands out. This form of organization seems to be related to the structure of the families in this study. 

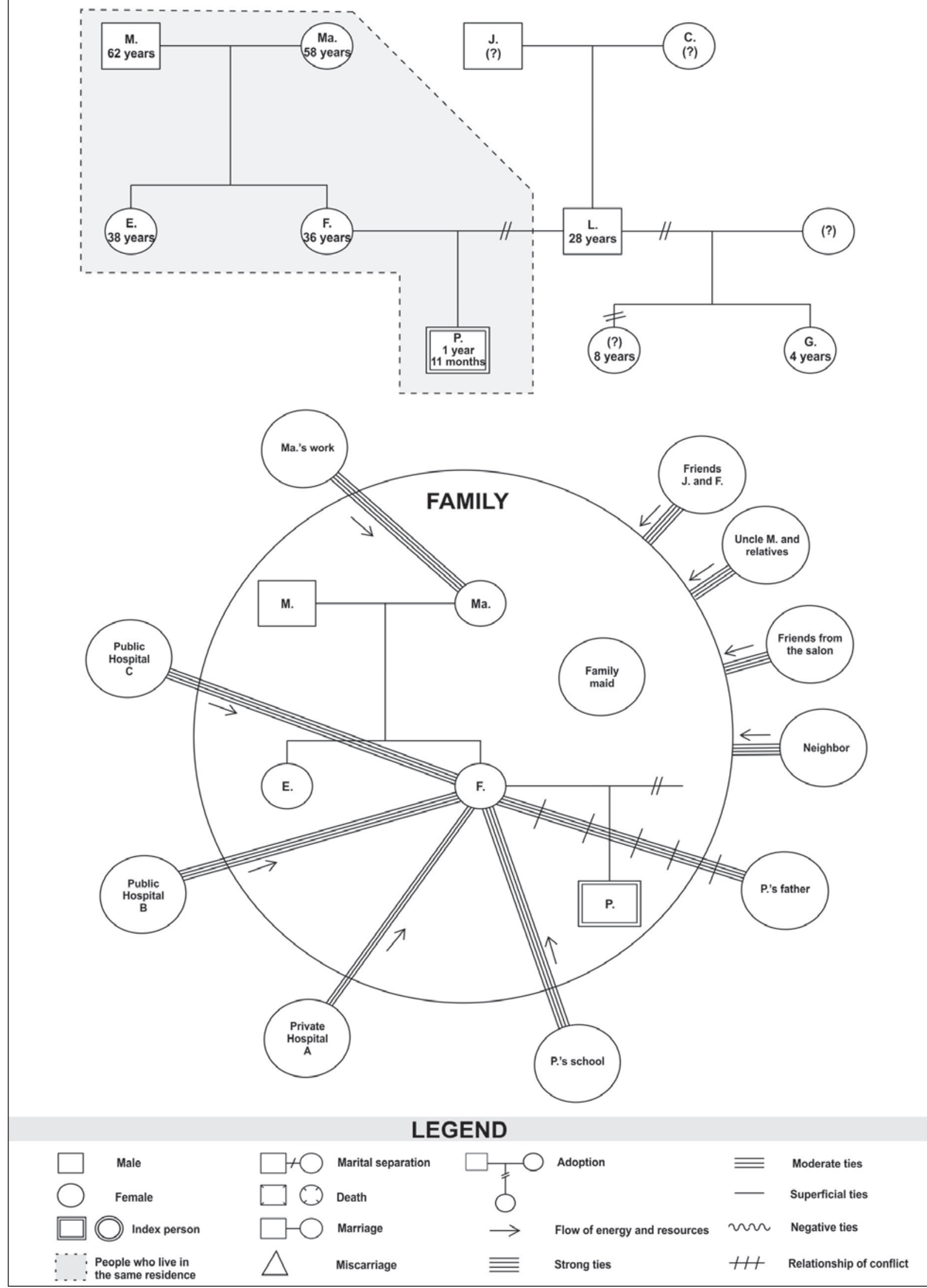

Figure 1 - Genogram and Ecomap - Pedro, 2012 
It is noticeable that this structure has undergone changes, due to changes occurring in society. Through the analysis of the genograms of the families participating in this study, it can be seen that the traditional model formed by the couple and the children was not prevalent. Thus, a plurality in the organizing of families can be observed. Some are formed by one of the parents and their offspring, without the presence of the other parent, as shown in Figure 1, for example, in addition to single or divorced mothers, and even couples who live in separate houses. Moreover, many families are formed by extended family members, such as parents, grandparents and other close relatives. Regarding the roles of family members, some women are responsible for the family income, or just contribute to it. In other situations, a father is responsible for taking care of the child and the household chores, while the mother works.

\section{DISCUSSION}

It appears that the organization of families is related to the demands presented by the children experienced in each moment. From the study, it can be seen that the organization and family structure are formed when faced with the initial demands, and that they adjust over time and with changes in clinical status.

The need for care at home after discharge from the hospital generated anxiety in the mothers. They felt insecure and scared, despite the living and learning gained while still in the hospital environment. The findings of some studies strengthen assertions regarding the insecurity of parents in the household, reaffirming the existence of a sense of fear and insecurity with the child coming the home, which may require support to address this reality. ${ }^{14}$

Thus, it can be inferred that the change of environment can also imply relearning the care. This signals the importance, in the period before hospital discharge, of preparing the family for home care, considering its context, which may require, in addition to honest dialogue with the family in order to help them understand the reality, a home visit from a professional. Such actions are essential for continuity of care.

The nurses involved in the care of these families have an important role at this time. They should minimize the repercussions of child care at home and provide focused attention to the needs of these individuals. Furthermore, they should stimulate the families' coping mechanisms. ${ }^{15}$
Considering the actual characteristics of the chronic conditions, the chance of occurrence of acute events meant the family had to live with the possibility of hospitalization, which greatly influenced the way the family members offered care. Perhaps because of the fragility of children with chronic conditions, and also depending on the life history of each child, and understanding about the condition of the child's mother, there is an increase in protection and care by some family members, possibly in an attempt to reduce possible risks. However, some theorists speculate that, although overprotection also characterizes the form of care provided by families, often such conduct can lead to social isolation and restrictions on the ability of the children to have a normal childhood. 16

It is then necessary that the families of these children be considered in their singularities, because each may experience the disease and the worsening of the child's condition in a different way. ${ }^{8}$ In this sense, there has been growing interest in assessing the ability of the parents of each child in order to promote the continuity of care provided to children with chronic conditions. ${ }^{9}$

It was found that after the initial moment of discharge, the care ended up differing from one child to another. This difference reported by family members may be related to the basic pathologies of the children, as some tend to stabilize while others do not. On the other hand, it is also possible that some families have acquired greater control over the child's condition and are able to better manage the demand for health services.

It should be noted that, although family members emphasize some of the care they provide to children with chronic conditions, the same kinds of care are sometimes necessary for any child. However, some of them, such as those related to feeding, adaptations in the home, the need to stimulate the child, and the constant need for professional care and dependency on medications, are included in the concept of chronic conditions adopted in this study. Studies show that the use of medications is the most common type of care to minimize or compensate for functional limitations in children who need special care, ${ }^{3-5}$ with drugs for asthma being the most used. ${ }^{17-18}$

It was apparent that the care provided by family members seems to be related to how the caregiver perceives the child and its potential. It was found that it is in the caring relationship that people are creating ways of taking care of children. 
It was evident that the organization of families to care for children with chronic conditions is related to how they perceive the care, the care facilities, and the impact on routine. Although the arrival of any new family member requires rearrangements, it appears that faced with the children's health condition and the limits this imposes on the families, it becomes more complicated to undertake rearrangements without feeling the interference in their lives so strongly. This assertion is consistent with the findings of a study conducted with families of children undergoing liver transplants. ${ }^{19}$

It can be noticed that when the women assume the care, whether they are mothers, aunts or grandmothers, it leads to changes in their lives. A similar situation was revealed in other studies that showed total or partial abandonment of employment, most often by the mother, to take care of the children. ${ }^{14,20-21}$ The fathers usually collaborate less in the child's care, especially as related to technological devices. ${ }^{14}$

Although in most cases the mothers assume the care, ${ }^{22}$ the constant presence of other family members and, at times, friends and neighbors, for assistance in caring for children with chronic conditions is remarkable, findings also identified in other studies. ${ }^{16,21}$ Family members and those people who are closest to the family weave networks of care, in the search for conditions that will meet the children's needs, which increase the potential of family care. ${ }^{23}$

From the transcripts, it was possible to recognize changes in the daily life of the family in caring for a child with a chronic condition. Among the noteworthy changes: the abandonment of employment; the need to balance housework with care; changes in schedules and in the home environment; and difficulties related to leisure. The literature indicates that the need for restructuring their way of life leads families to forgo activities previously undertaken by them, such as work, study, social life, leisure and self-care, which may have implications for their physical and mental health. ${ }^{8}$ In this sense, studies have been conducted, whose focus is the care routine of these families and the changes that have taken place. ${ }^{11,24}$

Because of changes in family routine, a redefinition of family roles and a link between its members is necessary, so that care can be performed. This coordination happens dynamically and is based upon the demands that arise. It is believed that, despite the conformations of families, all of them go through difficult events that cause changes, triggering reorganization of the roles and rules established before the illness. ${ }^{11,19,24}$

This imposes on the health professionals involved in child care different ways of caring for these families and assisting in mobilizing the resources available to cope with the condition and adaptation. ${ }^{19,20}$ The importance of professionals being inserted into the family context has been shown, in order to know its structure and the social network of the family, and identify the needs of this group, so they can plan the assistance and provide comprehensive care to all members. This support is critical for maintaining balance and family dynamics, and the professional can assist families with this process. ${ }^{7,19}$

Shifting the location of care from the hospital to the family's everyday environment allows the potential for continuity of care to arise from links other than the professional-client relationship, such as the specific networks particular to this personal space. These links can stimulate a relationship of co-responsibility with health professionals, allowing new roles for the agents of care. ${ }^{25}$

\section{FINAL CONSIDERATIONS}

Adaptations are necessary for the realization of home care, engendering a new way for families to care for children with chronic conditions. Given this reality, the importance of the performance of professionals in the preparation of the family for this new phase is explicit. That is because this transition represents a critical moment and a period of great stress for those who experience it, emphasizing the centrality of the mother's care and of greater organization. This fact points to the need for the family to participate in care before hospital discharge, so that they are able to develop it without creating dependency on the mother figure.

The care that family members point out as necessary for the child shows converging points, compared to the initial care required in the home, determining changes in many aspects of the lives of caregivers, who rely on the cooperation from their social network. Family support is expressed through the sharing of housework and child care, material resources and emotional support.

Despite the involvement of the family, the role of caregiver is delegated to the mothers and grandmothers of the children and, therefore, the impact on routine seems to be more intense in 
their lives. Despite the different conformations of the families, to enable this care, the constant presence of sources of social support was seen, represented by members of the extended family, friends and neighbors. Social interactions that occur between families and the sources of support are related to the way these groups are structured. These findings were attained by use of genograms and ecomaps, which allowed understanding of indicators of how families organized themselves.

This study was a snippet of that context and it is considered essential to deepen the knowledge of these families, since they are the ones who enable care. For this reason, it is important to see them as subjects of this process and encourage practices for their care, promoting greater visibility for this group of people to enable them to contribute to the continuity of care for children with chronic health conditions. Therefore, it is important to rethink the care model that has previously guided care for these children and their families, as well as the training of health professionals inserted in this context.

\section{ACKNOWLEDGMENTS}

Thanks to the Foundation for Research Support in the State of Minas Gerais (FAPEMIG).

\section{REFERENCE}

1. Stein RE, Bauman LJ, Westbrook LE, Coupey MS, Ireys HT. Framework for identifying children who have chronic conditions: the case for a new definition. J Pediatr. 1993 Mar; 122(3):342-7.

2. Duarte ED, Sena RR, Tavares TS. Práticas cuidadoras que favorecem a integralidade do cuidado ao recémnascidos de alto risco: revisão sistemática. Rev Eletr Enferm. 2010; 57(3): 539-46.

3. Hack M, Schluchter M, Andreias L, Margevicius S, Taylor HG, Drotar D, et al. Change in prevalence of chronic conditions between childhood and adolescence among extremely low-birth-weight children. JAMA. 2011 Jul; 306(4):394-401.

4. Leversen KT, Sommerfelt K, Ronnestad A, Kaaresen PI, Farstad T, Skranes J, et al. Prediction of neurodevelopmental and sensory outcome at 5 years in Norwegian children born extremely preterm. Pediatrics. 2011 Mar; 127(3):630-8.

5. Nageswaran S, Silver EJ, Stein RE. Association of functional limitation with health care needs and experiences of children with special health care needs. Pediatrics. 2008 Mai; 121(5): 994-1001.

6. Neves ET, Cabral IE. A fragilidade clínica e a vulnerabilidade social das crianças com necessidades especiais de saúde. Rev Gaúch Enferm. 2008 Jun; 29(2):182-90.

7. Vieira CS, Mello DF. O seguimento da saúde da criança pré-termo e de baixo peso egressa da Unidade de Terapia Intensiva Neonatal. Texto Contexto Enferm. 2009 Jan-Mar; 18(1):74-82.

8. Leite MF, Gomes IP, Leite MF, Gonçalves RGO, Rosin J, Collet N. Condição crônica na infância durante a hospitalização: sofrimento do cuidador familiar. Ciênc Cuid Saúde. 2012 Jan-Mar; 11(1):51-7.

9. Miller AR, Condin CJ, Mckellin WH, Shaw N, Klassen AF, Sheps S. Continuity of care for children with complex chronic health conditions: parent's perspectives. BMC Health Serv Res. 2009 Dec; 9(242):1-11.

10. Bellato R, Araújo LFS, Faria APS, et al. Itinerários terapêuticos da famílias e redes para o cuidado na condição crônica: alguns pressupostos. IN: Pinheiro R, Martins PH (org.). Avaliação em saúde na perspectiva do usuário: abordagem multicêntrica. Rio de Janeiro (RJ). UERJ: Abrasco; 2011.

11. Wright LM, Leahey M. Enfermeiras e famílias: um guia para avaliação e intervenção na família. $2^{a}$ ed. São Paulo (SP): Roca; 2009.

12. Knafl K, Deatrick JA. Further refinement of the family management style framework. J Family Nurs. 2003 Ago; 9(2):232-56.

13. Bardin L. Análise de conteúdo. São Paulo (SP): Editora 70; 2008.

14. Guerini IC, Cordeiro PKS, Osta SZ, Ribeiro EM. Percepção de familiares sobre estressores decorrentes das demandas de cuidado de criança e adolescente dependentes de tecnologias. Texto Contexto Enferm. 2012 Abr-Jun; 21(2):348-55.

15. Vieira CS, Mello DF, Oliveira BRG. O seguimento do prematuro e baixo peso ao nascer egresso da terapia intensiva neonatal na família: uma revisão de literatura. OBJN. 2008; 7(3):74-82.

16. Silveira A, Neves ET. Crianças com necessidades especiais em saúde: cuidado familiar na preservação da vida. Cienc Cuid Saúde. 2012 Jan-Mar; 11(1):7480 .

17. Farooqi A, Hagglof B, Sedin G, Gothefors L, Serenius F. Chronic conditions, functional limitations, and special health care needs in 10- to 12-year-old children born at 23 to 25 weeks' gestation in the 1990s: a Swedish national prospective follow-up study. Pediatrics. 2006 Nov; 118(5):1466-77.

18. Hack M, Taylor HG, Drotar D, Schluchter M, Cartar R, Andreias L, et al. Chronic conditions, functional limitations, and special health care needs of schoolaged children born with extremely low-birth-weight in the 1990s. JAMA. 2005 Jul; 94(3):318-25.

19. Mendes-Castilho AMC. Manejo familiar no transplante hepático da criança. [Tese] São Paulo (SP): Universidade de São Paulo. Escola de Enfermagem; 2011. 
20. Silva R, Collet N, Silva KL, Moura FM. Cotidiano da família no enfrentamento da condição crônica na infância. Acta Paul Enferm. 2010; 23(3):359-65.

21. Milbrath VM, Cecagno D, Soares DC, Amestoy SC, Siqueira $\mathrm{HCH}$. Ser mulher mãe de uma criança portadora de paralisia cerebral. Acta Paul Enferm. 2008; 21(3):427-31.

22. Vrijmoet-Wiersma CMJ, Van Klink JMM, Kolk AM, Koopman HM, Ball LM, Egeler R.M. Assesment of parental psyschological stress in pediatric cancer: a review. J Pediatr Pshychol. 2008 Aug; 33(7):694-706.
23. Nepomuceno MAS, Bellato R, Araújo LFS, Mufato LF. Modos de tessitura de redes para o cuidado pela família que vivencia a condição crônica por adrenoleucodistrofia. Cienc Cuid Saude. 2012; 11(1):156-65.

24. Denham SA. Relationships between family ritual, family routines and health. J. Fam Nursing. 2003 Ago; 9(3):305-30.

25. Carvalho M, Gomes MASM. A mortalidade do prematuro extremo em nosso meio: realidade e desafios. J Pediatr. 2005; 81(1):111-7. 